\title{
Tinjauan Konsep Desain Berkelanjutan pada Arsitektur Rumah Tinggal di Desa Adat Kampung Naga
}

\author{
${ }^{1}$ Febry Maharlika,S.Ds.,M.Sn | ${ }^{2}$ Dina Fatimah,M.Ds. | \\ Program Studi Desain Interior,Universitas Komputer Indonesia, Bandung \\ Email: febry.maharlika@email.unikom.ac.id, dina.fatimah@email.unikom.ac.id
}

\begin{abstract}
ABSTRAK
Penelitian ini bertujuan untuk memaparkan sistem desain berkelanjutan pada arsitektur rumah tinggal di Kampung Naga, Jawa Barat. Kampung naga adalah salah satu kampung adat Sunda yang masih melestarikan dan melaksanakan pakem- pakem yang ada pada masyarakatnya secara turun temurun. Pelaksanaan sistem kemasyarakatan tersebut salah satunya terwujud pada desain arsitektur rumah tinggal penduduknya. Dengan pemahaman keselarasan dengan alam, manusia, dan Tuhan, arsitektur rumah tinggal di kampung naga memiliki kekhasan tersendiri. Yang lebih menarik, desain arsitektur rumah tinggal ini mencerminkan desain berkelanjutan yang sekarang ini marak digunakan oleh para desainer dunia. Metode yang digunakan pada penelitian ini adalah analisis deskriptif dengan data kualitatif. Penelitian memaparkan setiap elemen interior yang memenuhi kategori konsep desain berkelanjutan pada rumah tinggal di Kampung Naga. Kategori tersebut diantaranya: pencahayaan, kualitas udara di dalam ruangan, pemanas surya pasif, saluran udara alami, efisiensi energi, pemanfaatan energi, minimalisasi limbah konstruksi konservasi air, pengelolaan limbah padat, energi terbarukan, lansekap alam dan pelestarian lahan. Hasil analisis menunjukkan bahwa arsitektur rumah tinggal Kampung Naga memenuhi kategori desain berkelanjutan. Pemenuhan kategori tersebut bertujuan untuk merepresentasikan interaksi yang seimbang antara pembangunan manusia dan alam.
\end{abstract}

Kata Kunci: arsitektur, rumah tinggal, kampung naga, desain berkelanjutan

\begin{abstract}
This study aims to describe a sustainable design system in residential architecture in Kampung Naga, West Java. Kampung Naga is one of the traditional Sundanese villages that still preserves and implements the norms that have existed in the community for generations. One of the implementation of the social system was manifested in the architectural design of the residents' houses. By understanding harmony with nature, humans, and God, the architecture of houses in the dragon village has its own peculiarities. More interestingly, the architectural design of this residence reflects the sustainable design that is now widely used by world designers. The method used in this study is descriptive analysis with qualitative data. The research describes every interior element that meets the category of sustainable design concepts in homes in Kampung Naga. These categories include: lighting, indoor air quality, passive solar heating, natural airways, energy efficiency, energy utilization, minimization of water conservation construction waste, solid waste management, renewable energy, natural landscape and land preservation. The results of the analysis show that the architecture of Kampung Naga residences meets the category of sustainable design. The fulfillment of these categories aims to represent a balanced interaction between human and natural development.
\end{abstract}

Keywords: architecture, residential house, kampung naga, sustainable design

\section{PENDAHULUAN}

Kampung Naga merupakan kampung adat sunda yang masih memegang adat istiadat yang diturunkan dari para leluhurnya. Pakem- pakem yang telah ada, dipatuhi oleh masyarakatnya sebagai bentuk usaha untuk mencapai keseimbangan hidup manusia dengan alam maupun dengan Tuhan. Salah satu wujudnya adalah rumah tinggal yang ada disana. Rumah tinggal yang ada di Kampung Naga berjumlah 110 unit, tidak boleh kurang dan tidak boleh lebih. Bentuknya pun seluruhnya serupa sesuai dengan pakem yang telah ditentukan. Di kampung 
ini, tidak diperbolehkan adanya listrik, ataupun hal lain yang berkaitan dengan teknologi modern.

Berdasarkan observasi yang dilakukan, ditemukan indikasi bahwa desain arsitektur rumah tinggal di Kampung Naga memiliki konsep desain berkelanjutan. Desain berkelanjutan sendiri saat ini telah marak di seluruh dunia dengan pertimbangan untuk mempertahankan kelestarian alam, keadilan sosial dan ekonomi. Sedangkan Kampung Naga telah menggunakan sistem tersebut sejak berabadabad lamanya.

Dari sudut pandang pencapain keseimbangan hidup yang selaras dengan alam, arsitektur rumah tinggal di Kampung Naga dapat menjadi acuan bagaimana seharusnya masyarakat sunda atau masyarakat yang tinggal di tanah sunda mendesain rumah tinggalnya. Alam menjadi salah satu pertimbangan untuk membangun ruang hunian, agar mencapai kehidupan yang seimbang sehingga kebahagiaan dapat tercapai. Paparan hasil penelitian dapat menjadi pertimbangan bagaimana rumah tinggal yang dapat melestarikan alamnya, pencapaian keadilan sosial dan ekonomi.

\section{METODE}

Penelitian ini menggunakan metode analisis deskriptif dengan pendekatan kualitatif. Menurut Ratna (2010:336) metode analisis deskriptif adalah metode yang digunakan untuk menguraikan sekaligus menganalisis. Penelitian yang tinjauan konsep desain berkelanjutan pada arsitektur rumah tinggal di kampung naga ini akan menganalisis sekaligus mendeskripsikan elemen-elemen arsitektural dan interior yang memenuhi konsep desain berkelanjutan.

Pada penelitian ini, data yang digunakan adalah data kualitatif, yang artinya data-data yang didapat bukan berupa data numerik yang datanya merupakan hubungan signifikan antara objek penelitian dengan subjek peneliti. Tahapan dari penelitian ini adalah mengumpulkan data kualitatif arsitektur rumah tinggal di Kampung Naga, kemudian akan dianalisis sesuai dengan kategori desain berkelanjutan.

\section{PEMBAHASAN}

\section{A. Tinjauan Kampung Naga}

Kampung Naga adalah perkampungan yang dihuni oleh masyarakat sunda, kawasan ini berada di Desa Neglasari, Kecamatan Salawu Kabupaten Tasikmalaya. Kampung ini berada pada suatu cekungan atau lembah perbukitan dengan ketinggian $690 \mathrm{~m}$ diatas permukaan laut. Suhu udara sejuk dengan suhu rata-rata $21,5^{\circ-} 23^{\circ} \mathrm{C}$. Luas keseluruhan wilayah adat sekitar 4 hektar dengan wilayah perkampungan sebesar 10,5 ha meliputi lahan pemukiman, hutan, kebon dan sawah. Wilayah Kampung Naga dibagi menjadi tiga bagian yakni Leweung Keramat (makam nenek moyang) yang terletak di sebelah barat, perkampungan warga yang terletak di bagian tengah, dan Leweung Larangan yang terletak di sebelah timur. Bangunan yang terdapat disana berjumlah 113 bangunan, yang terdiri dari 110 bangunan rumah tinggal, dan 3 bangunan khusus, diantaranya bale patemo),masjid dan Bumi Agung.

Pemukiman kampung naga terletak di lereng bukit. Hal tersebut menjadikan nama Kampung Naga, $\mathrm{Na}-$ $\mathrm{Ga}$ merupakan penggalan kata yang diambil dari bahasa sunda yaitu kata dina yang berarti berada disedangkan $G a$ diambil dari kata gawir, yang berarti lereng atau tebing. Sehingga Kampung Naga berarti kampung yang terletak di lereng.

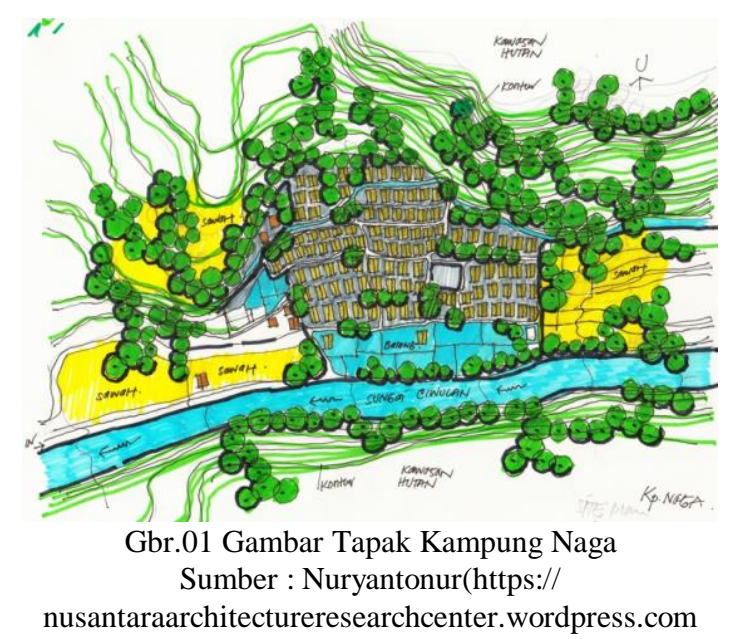

Kampung Naga terletak di antara tebing- tebing yang menyebabkan kondisi tanahnya berkontur. Kontur tanah yang berundak menyebabkan bangunan yang ada di atasnya memliki perbedaan letak ketinggian. Walaupun berada di ketinggian tanah yang berbeda, bentuk arsitektur rumah tinggal untuk masing-masing warga tetap disamakan. Pembangunan yang dilakukan di Kampung Naga dilakukan secara gotong royong oleh semua warga. Tidak ada penggunaan material pabrikasi yang diterapkan pada seluruh bangunan yang ada di Kampung Naga. Seluruhnya didapatkan dari hutan sekitar yang memang sengaja diperuntukan untuk mendukung pembangunan di kampung adat ini. 


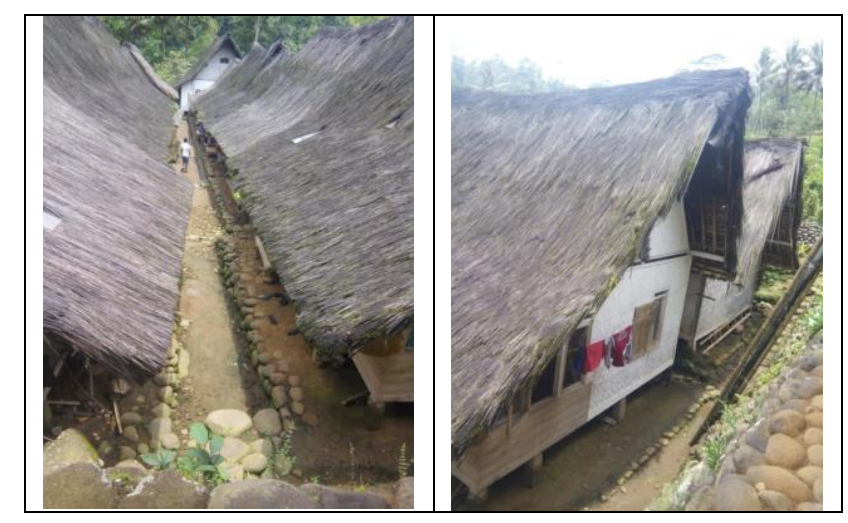

Gbr.02 Kawasan Kampung Naga

Sumber : Satriyani (http://inayirtas.blogspot.co.id/)

\section{B. Tinjauan Arsitektur Rumah Tinggal di Kampung Naga}

Rumah tinggal yang ada di Kampung Naga berjumlah 110 unit dengan jumlah 110 kepala keluarga. Ketentuan adat istiadat mengaharuskan setiap keluarga hanya boleh memiliki satu kepala keluarga sehingga jika ada keturunan yang menikah, maka diharuskan keluar dari Kampung Naga. Kepemilikan rumah di Kampung Naga diwariskan secara turun temurun melalui anak perempuan tertua.

Letak rumah-rumah di Kampung Naga menyebar sesuai dengan lahan yang disediakan oleh aturan adat. Sebagian besar rumah berjajar saling berhadapan, dan diharuskan menghadap arah utara dan selatan.

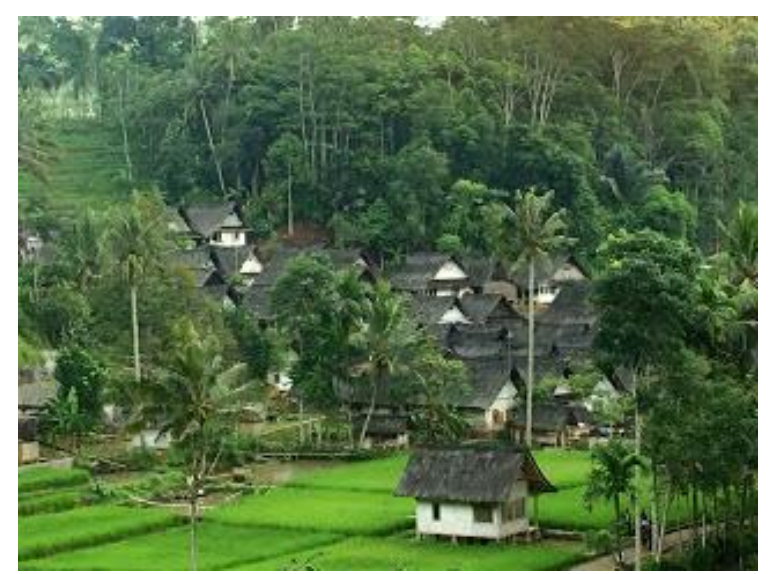

Gbr.03 Lingkungan Pemukiman di Kampung Naga Sumber : Dokumentasi Penulis (2016)
Seperti rumah adat sunda lainnya, rumah tinggal di Kampung naga terdiri dari Ruangan depan (tepas/emper), Ruangan samping/ kamar (pangkeng) Ruangan tengah (tengah imah/petengahan), dan ruangan belakang yang terdiri dari tempat menyimpan beras, yang disebut Goah dan dapur (pawon) dan. Berikut adalah tata letak ruang di rumah tinggal Kampung Naga.

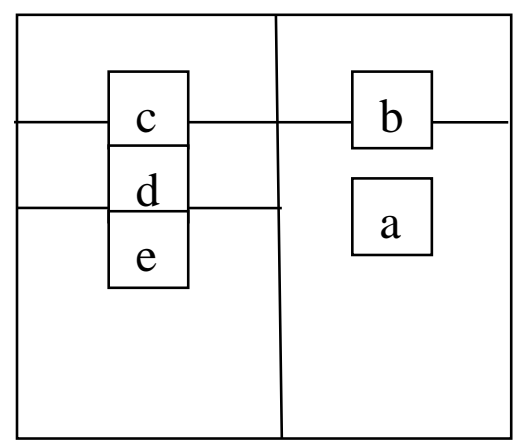

Gbr.04 Denah Rumah Tinggal di Kampung Naga Sumber : Data Penulis (2018)

\begin{tabular}{|l|}
\hline $\mathrm{a}:$ Ruangan depan/tepas \\
$\mathrm{b}:$ Ruangan samping/pangkeng \\
$\mathrm{c}:$ Ruangan tengah \\
/patengahan \\
$\mathrm{d}:$ Goah \\
$\mathrm{e}:$ Dapur / Pawon
\end{tabular}

Bentuk atap pada arsitektur rumah tinggal di Kampung Naga menggunakan bentuk atap Julang Ngapak. Bentuk atap julang ngaapak adalah bentuk atap yang melebar di kedua bidang sisinya menyerupai sayap dari burung julang yang sedang merentang.

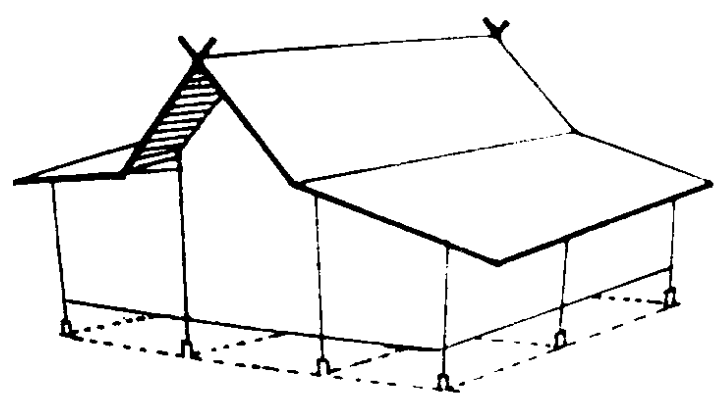

Gbr.05 Bentuk atap Julang ngapak

Sumber : Departemen Pendidikan dan Kebudayaan $(1981 / 1982)$ 


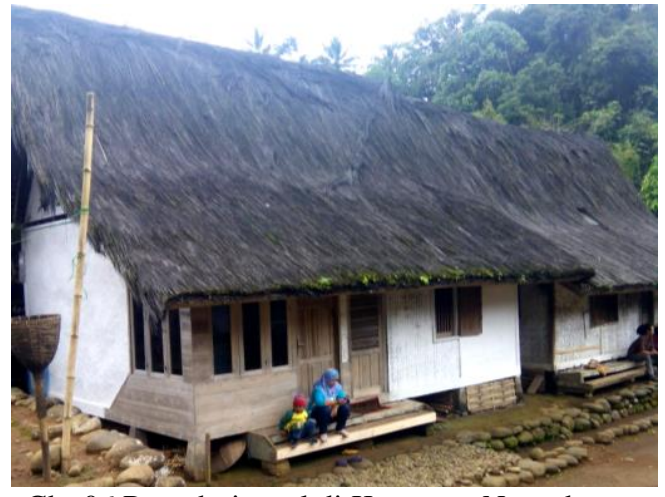

Gbr.06 Rumah tinggal di Kampung Naga dengan atap julang ngapak

Sumber : Dokumentasi penulis (2016)

Elemen interior yang mengisi ruang dibuat dengan konsep tradisional. Semua bangunan yang ada di Kampung Naga tidak diperbolehkan menggunakan listrik, maka untuk penerangan pada malam hari, warga menggunakan alat penerangan tradisional yaitu cempor yang berbahan baku minyak tanah. Sedangkan untuk siang hari, pencahayaan alami yang berasal dari cahaya matahari masuk ke dalam rumah, melalui bukaan jendela, maupun dari bagian lubang di atap yang di tutup oleh material transparan sehingga cahaya matahari dapat masuk.

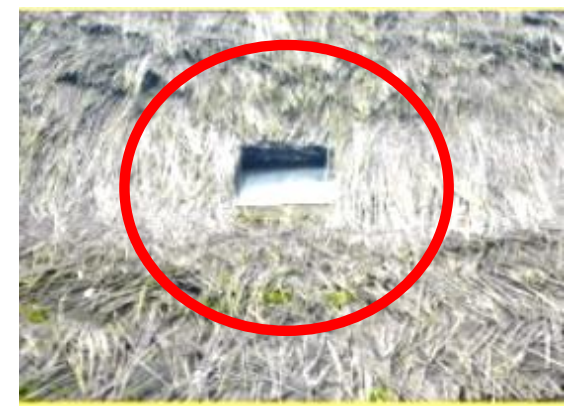

Gbr.07 Lubang pada Atap sebagai Pencahayaan Alami Sumber : Dokumentasi Penulis (2016)

Selain pencahayaan yang cukup baik, kualitas udara di dalam rumah pun sangat baik, dikarenakan udara yang masuk dan udara yang keluar tersalur dengan baik melalui konsep desain panggung pada rumah, material dinding berupa anyaman bambu sehingga ada celah tempat keluar masuknya udara, desain pintu yang juga menggunakan anyaman, dan terdapat juga lubang-lubang ventilasi yang berada di bagian dinding atas rumah.

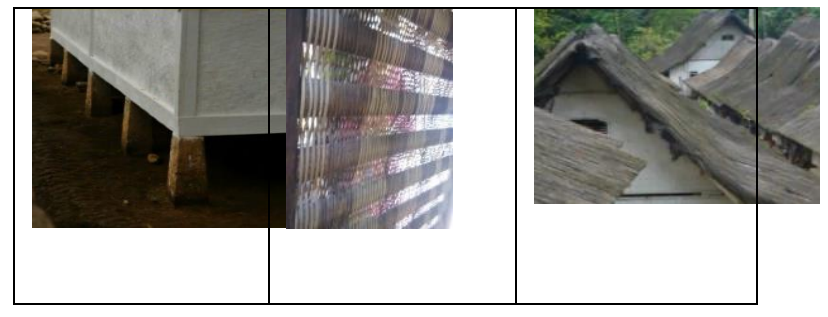

Gbr.08 Konsep Penghawaan pada Rumah Tinggal kampung Naga

Sumber : Dokumentasi Penulis (2016)

\section{Tinjauan Konsep Desain Berkelanjutan}

Pembangunan berkelanjutan adalah pembangunan yang memenuhi kebutuhan masa kini, tanpa mengorbankan kemampuan atau potensi generasi mendatang untuk memenuhi kebutuhan mereka sendiri. Keberlanjutan mempresentasikan interaksi yang seimbang antara pembangunan manusia dan alam. Interaksi antara manusia dan alam sering kali ditunjukan dengan tiga komponen, yaitu : lingkungan, keadilan sosial dan ekonomi. Hubungan antara masing-masing elemen tersebut, dapat dipresentasikan dalam diagram venn, dengan sistem berkelanjutan merupakan hasil irisan dari ketiga elemen tersebut.

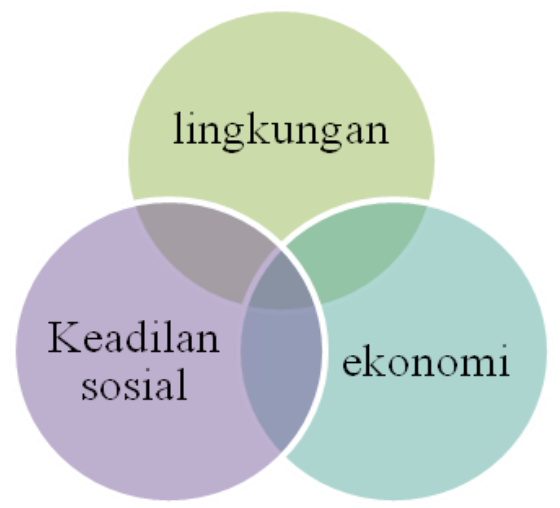

Gbr.09 Konsep Diagram Venn Hubungan antara Lingkungan, Keadilan Sosial dan Ekonomi Sumber : Data Penulis (2017)

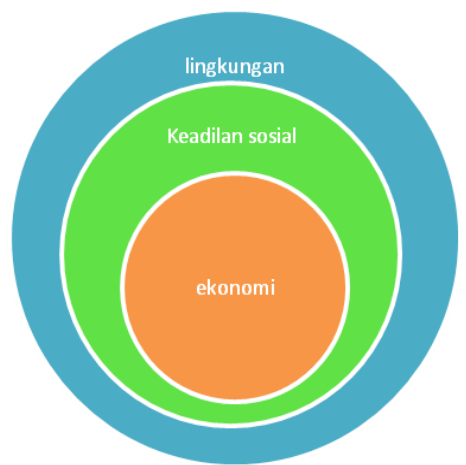

Gbr.10 Lingkaran Konsentris yang Menunjukan hubungan antara Lingkungan,

Keadilan Sosial dan Ekonomi Sumber : Data Penulis (2017)

Lingkaran konsentris di atas mencerminkan ekonomi yang sehat tergantung pada masyarakat yang sehat, baik yang bergantung pada lingkungan yang sehat. Berkelanjutan terjadi ketika ketiganya berkembang. Berikut adalah kategori Kategori yang dapat menjadi acuan dalam pembuatan konsep desain yang berkelanjutan, bagaimana bangunan di rancang, dibangun dan digunakan 
1. Pencahayaan

2. Kualitas udara dalam ruangan

3. Pemanas surya pasif

4. Saluran udara alami

5. Efisiensi energi

6. Pemanfaatan energi

7. Minimalisasi limbah konstruksi

8. Konservasi air

9. Pengelolaan limbah padat

10. Energi terbarukan

11. Lansekap alam

12. Pelestarian lahan

\section{Ringkasan Tinjauan Desain berkelanjutan pada aspek ekonomi, lingkunan dan keadilan sosial.}

Tabel 1. Tinjauan Desain berkelanjutan pada aspek ekonomi

Sumber :Penulis (2018)

\begin{tabular}{|c|c|c|}
\hline No & $\begin{array}{l}\text { Kategori desain } \\
\text { berkelanjutan }\end{array}$ & Keterangan \\
\hline 1 & Pencahayaan & $\begin{array}{l}\text { Penghematan penggunaan } \\
\text { minyak tanah dengan } \\
\text { pemanfaatan sumber } \\
\text { pencahayaan alami yang di } \\
\text { dapat dari bukaan berupa } \\
\text { jendela dan penggunaan } \\
\text { material polikarbonat pada } \\
\text { bagian atap }\end{array}$ \\
\hline 2 & $\begin{array}{l}\text { Kualitas udara } \\
\text { dalam ruangan }\end{array}$ & $\begin{array}{l}\text { Tidak memerlukan pendingin } \\
\text { atau penghangat ruangan. } \\
\text { Penggunaan jendela jalusi } \\
\text { mengatur pertukaran udara } \\
\text { dengan baik. Selain itu } \\
\text { penggunaan palupuh sebagai } \\
\text { lantai rumah dapat } \\
\text { menghangatkan suasana udara } \\
\text { dalam ruangan. }\end{array}$ \\
\hline 3 & Pemanas surya pasif & - \\
\hline 4 & Saluran udara alami & $\begin{array}{l}\text { Penggunaan jendela jalusi } \\
\text { mengatur pertukaran udara } \\
\text { dengan baik sehingga tidak } \\
\text { memerlukan pengatur udara } \\
\text { buatan yang memerlukan } \\
\text { energi lain }\end{array}$ \\
\hline 5 & Efisiensi energi & $\begin{array}{l}\text { Pemanfaatan pencahayaan } \\
\text { alami dan saluran udara alami } \\
\text { membuat energi lebih efisien }\end{array}$ \\
\hline 6 & Pemanfaatan energi & $\begin{array}{l}\text { Pemanfaatan energi matahari } \\
\text { sangat dimanfaatkan dalam } \\
\text { arsitektur rumah, sehingga } \\
\text { lebih ekonomis }\end{array}$ \\
\hline 7 & $\begin{array}{l}\text { Minimalisasi } \\
\text { limbah konstruksi }\end{array}$ & $\begin{array}{l}\text { Dengan desain yang ada, } \\
\text { pemanfaatan material diipilih } \\
\text { secara seksama, sehingga } \\
\text { meminimalisir penggantian } \\
\text { material dalam jangka waktu } \\
\text { lama. }\end{array}$ \\
\hline 8 & Konservasi air & $\begin{array}{l}\text { Pemanfaatan air dilakukan } \\
\text { secara terpusat, warga } \\
\text { menggunakan air di area } \\
\text { terpisah dari rumah tinggal, } \\
\text { dalam hal ini air yang } \\
\text { digunakan adalah air yang } \\
\text { berasal dari pegunungan yang } \\
\text { selalu mengalir. Tidak ada } \\
\text { konservasi khusus. }\end{array}$ \\
\hline
\end{tabular}

\begin{tabular}{|l|l|l|}
\hline 9 & Pengelolaan limbah & $\begin{array}{l}\text { Limbah padat berupa sampah } \\
\text { dapat digunakan untuk } \\
\text { makanan ikan yang } \\
\text { tertampung pada bagian } \\
\text { kolam. Sedangkan limbah } \\
\text { lainnya dibakar atau dijadikan } \\
\text { barang kerajinan yang dapat } \\
\text { dijual }\end{array}$ \\
\hline 10 & Energi terbarukan & - \\
\hline 11 & Lansekap alam & - \\
\hline 12 & Pelestarian lahan & $\begin{array}{l}\text { Lahan diatur untuk } \\
\text { pembangunan rumah tanpa } \\
\text { membuka lahan baru yang } \\
\text { digunakan untuk area } \\
\text { penghijauan }\end{array}$ \\
\hline & &
\end{tabular}

Tabel 2. Tinjauan Desain berkelanjutan pada aspek lingkungan

Sumber :Penulis (2018)

\begin{tabular}{|c|c|c|}
\hline No & $\begin{array}{l}\text { Kategori desain } \\
\text { berkelanjutan }\end{array}$ & Keterangan \\
\hline 1 & Pencahayaan & $\begin{array}{l}\text { Sumber pencahayaan alami yang } \\
\text { didapat dari bukaan berupa jendela dan } \\
\text { penggunaan material polikarbonat pada } \\
\text { bagian atap. Hal tersebut tentunya } \\
\text { membuat desain rumah ini ramah } \\
\text { lingkungan }\end{array}$ \\
\hline 2 & $\begin{array}{l}\text { Kualitas udara dalam } \\
\text { ruangan }\end{array}$ & $\begin{array}{l}\text { Penggunaan jendela jalusi mengatur } \\
\text { pertukaran udara dengan baik. Tidak } \\
\text { menggunakan alat yang dapat merusak } \\
\text { lingkungannya. }\end{array}$ \\
\hline 3 & Pemanas surya pasif & - \\
\hline 4 & Saluran udara alami & $\begin{array}{l}\text { Penggunaan jendela jalusi mengatur } \\
\text { pertukaran udara dengan baik sehingga } \\
\text { tidak memerlukan pengatur udara } \\
\text { buatan }\end{array}$ \\
\hline 5 & Efisiensi energi & $\begin{array}{l}\text { Pemanfaatan pencahayaan alami dan } \\
\text { saluran udara alami membuat energi } \\
\text { lebih efisien }\end{array}$ \\
\hline 6 & Pemanfaatan energi & $\begin{array}{l}\text { Pemanfaatan energi matahari sangat } \\
\text { dimanfaatkan dalam arsitektur rumah. } \\
\text { Pemilihan bahan bangunan yang } \\
\text { didapat dari hutan khusus yang selalu } \\
\text { terbarukan. }\end{array}$ \\
\hline 7 & $\begin{array}{l}\text { Minimalisasi limbah } \\
\text { konstruksi }\end{array}$ & $\begin{array}{l}\text { Dengan desain yang ada, pemanfaatan } \\
\text { material diipilih secara seksama, } \\
\text { sehingga meminimalisir penggantian } \\
\text { material dalam jangka waktu lama } \\
\text { sehingga tidak menebang pohon secara } \\
\text { terus menerus. }\end{array}$ \\
\hline 8 & Konservasi air & $\begin{array}{l}\text { Pemanfaatan air dilakukan secara } \\
\text { terpusat, warga menggunakan air di } \\
\text { area terpisah dari rumah tinggal, dalam } \\
\text { hal ini air yang digunakan adalah air } \\
\text { yang berasal dari pegunungan yang } \\
\text { selalu mengalir. }\end{array}$ \\
\hline 9 & $\begin{array}{l}\text { Pengelolaan limbah } \\
\text { padat }\end{array}$ & $\begin{array}{l}\text { Limbah padat berupa sampah dapat } \\
\text { digunakan untuk makanan ikan yang } \\
\text { tertampung pada bagian kolam. } \\
\text { Sedangkan limbah lainnya dibakar atau } \\
\text { dijadikan barang kerajinan yang dapat } \\
\text { dijual. Sehingga limbah tersebut tidak } \\
\text { mencemari lingkungan sekitar. }\end{array}$ \\
\hline 10 & Energi terbarukan & - \\
\hline 11 & Lansekap alam & $\begin{array}{l}\text { Pengaturan lahan yang sangat } \\
\text { konsisten membuat lansekap alam desa } \\
\text { ini masih tetap dalam keadaan baik }\end{array}$ \\
\hline 12 & Pelestarian lahan & $\begin{array}{l}\text { Lahan diatur untuk pembangunan } \\
\text { rumah tanpa membuka lahan baru } \\
\text { yang digunakan untuk area } \\
\text { penghijauan }\end{array}$ \\
\hline
\end{tabular}


Tabel 3. Tinjauan Desain berkelanjutan pada aspek keadilan sosial

Sumber :Penulis (2018)

\begin{tabular}{|c|c|c|}
\hline No & $\begin{array}{l}\text { Kategori desain } \\
\text { berkelanjutan }\end{array}$ & Keterangan \\
\hline 1 & Pencahayaan & $\begin{array}{l}\text { Dengan memanfaatkan sumber } \\
\text { pencahayaan alami, pemerataan } \\
\text { sumber cahaya dapat dirasakan } \\
\text { seluruh warga Kampung Naga }\end{array}$ \\
\hline 2 & $\begin{array}{l}\text { Kualitas udara } \\
\text { dalam ruangan }\end{array}$ & $\begin{array}{l}\text { Dengan persamaan desain } \\
\text { rumah serta peletakan rumah } \\
\text { yang diatur, maka dapat } \\
\text { diasumsikan kualitas udara } \\
\text { dalam ruangan sama }\end{array}$ \\
\hline 3 & Pemanas surya pasif & - \\
\hline 4 & Saluran udara alami & $\begin{array}{l}\text { Dengan persamaan desain } \\
\text { rumah serta peletakan rumah } \\
\text { yang diatur, maka dapat } \\
\text { diasumsikan kualitas udara } \\
\text { dalam ruangan sama }\end{array}$ \\
\hline 5 & Efisiensi energi & $\begin{array}{l}\text { Pemanfaatan pencahayaan alami } \\
\text { dan saluran udara alami } \\
\text { membuat energi lebih efisien }\end{array}$ \\
\hline 6 & Pemanfaatan energi & $\begin{array}{l}\text { Penggunaan bahan bangunan } \\
\text { dilakukan sesuai kebutuhan } \\
\text { warga secara merata }\end{array}$ \\
\hline 7 & $\begin{array}{l}\text { Minimalisasi } \\
\text { limbah konstruksi }\end{array}$ & \\
\hline 8 & Konservasi air & $\begin{array}{l}\text { Pemanfaatan air dilakukan } \\
\text { secara terpusat, warga } \\
\text { menggunakan air di area } \\
\text { terpisah dari rumah tinggal, } \\
\text { dalam hal ini air yang } \\
\text { digunakan adalah air yang } \\
\text { berasal dari pegunungan yang } \\
\text { selalu mengalir. }\end{array}$ \\
\hline 9 & $\begin{array}{l}\text { Pengelolaan limbah } \\
\text { padat }\end{array}$ & - \\
\hline 10 & Energi terbarukan & - \\
\hline 11 & Lansekap alam & $\begin{array}{l}\text { Pengaturan lahan yang sangat } \\
\text { konsisten membuat lansekap } \\
\text { alam desa ini masih tetap dalam } \\
\text { keadaan baik dan setiap warga } \\
\text { telah mendapat bagian masing- } \\
\text { masing secara merata }\end{array}$ \\
\hline 12 & Pelestarian lahan & $\begin{array}{l}\text { Lahan diatur untuk } \\
\text { pembangunan rumah tanpa } \\
\text { membuka lahan baru yang } \\
\text { digunakan untuk area } \\
\text { penghijauan }\end{array}$ \\
\hline
\end{tabular}

\section{KESIMPULAN}

Desain arsitektur rumah tinggal di Kampung Naga setelah dipaparkan memenuhi kategori desain berkelanjutan. Rumah tinggal warga merupakan salah satu bagian dari sistem berkelanjutan yang dilakukan secara turun temurun demi kelangsungan hidup yang mencakup kebutuhan ekonomi, pelestarian lingkungan dan keadilan sosial. Warga Kampung Naga menerapkan keselarasan hidup antara sesama manusia, alam dan Tuhan, hal tersebut salah satunya tercermin dari arsitektur rumah tinggalnya yang mengandung sistem berkelanjutan. Dengan adanya penelitian ini, masyarakat jawa Barat pada khususnya memiliki acuan yang jelas mengenai arsitektur yang berkelanjutan demi keberlangsungan hidup anak cucu kelak.

\section{DAFTAR PUSTAKA}

[1]Departemen Pendidikan dan Kebudayaan.(1981/1982).Arsitektur Tradisional Daerah Jawa Barat. Departemen Pendidikan dan Kebudayaan

[2] Hermawan, Iwan.(2014). Bangunan Tradisional Kampung Naga : Bentuk Kearifan Warisan Leluhur Masyarakat Sunda,(daring).

http://www.journal.uinjkt.ac.id

[3]Frick,Heinz.,FX.Bambang

Suskiyanto.(2007).Dasar-dasar Arsitektur ekologis:Konsep Pembangunan Berkelanjutan dan Ramah Lingkungan.Kanisius:Yogyakarta.

[4]Nur ilham, Anggie.,Afriyanto Sofyan.(2012).Tipologi Bangunan Rumah Tinggal Adat Sunda di Kampung Naga Jawa Barat, (daring) http://www.journal.unika.ac.id

[5]Perdana, Reski Wahyu., Septi Asri Finanda.(2014).Buku Etnografi Kampung Naga Tasikmalaya, (daring). http://www.eprints.upnjatim.ac.id

[6]Permana,Sidik.(2015).Kampung Naga Pengetahuan ekologi tradisional dan Pelestarian Keanekaragaman Hayati Tumbuhan.Plantaxia: Yogyakarta.

[7]Priyoga,Iwan.(2010).Desain Berkelanjutan. (daring). http://www.jurnal.unpand.ac.id

[8]Ruggles,Rudy. ,Ashen Phansey \& Benjamin L. Guide to Sustainable Design. (daring). http://www.solidworks.com 